\title{
Varning för björntjänster! eller Hur värderas praktisk kunskap?
}

Pernilla Ahlstrand

Jag kommer i följande text att diskutera kursplaner inom estetiska programmets teaterinriktning där kursen Scenisk gestaltning I får fungera som exempel. Ämnes- och kursplanebeskrivningar implementerades i och med reformen GYI (Gymnasieskola 20II). Kursens innehåll ska vara vägledande för undervisningen.

Undervisningen i kursen ska behandla följande centrala innehåll:

- Kroppen och rösten som medel för att utrycka sig på scenen samt träning $i$ att använda kropp och röst i sceniska sammanhang.

- Träning i att använda teaterns andra uttrycksområden, till exempel scenografi, kostym, mask, ljus och ljud.

- Den sceniska berättelsens uppbyggnad med till exempel handling, karaktärer, tid och rum.

- Samspel mellan berättelse, berättare och rum i syfte att skapa en enhetlig gestaltning.

- Samverkan mellan ett av teaterns uttrycksområden och ett eller flera andra uttrycksområden. Det sceniska uttryckets förändring vid olika kombinationer av uttrycksområden.

- Träning i att medvetet förmedla tankar, känslor och åsikter till en publik.

- Teatern som kollektiv konstart med fokus på individuell kreativitet och samspel i grupp.

Hur du refererar till det här kapitlet:

Ahlstrand, P. 20I8. Varning för björntjänster! eller Hur värderas praktisk kunskap? I: von Schantz, U., Thorgersen, K. and Lidén, A. (red.) De estetiska ämnenas didaktik Utmaningar, processer och protester. Pp. 25-43. Stockholm: Stockholm University Press. DOI: https://doi.org/Io.I6993/ bap.b. License: CC-BY 
- Reflektion över det egna skapandet, både individuellt och i grupp.

- Analys och tolkning av sceniska gestaltningar med fokus på att särskilja teaterns olika uttrycksområden och hur en berättelse förmedlas.

- Begrepp för analys av form och innehåll i scenisk gestaltning.

\section{Kunskap som tar sig verbala, skriftliga och kroppsliga uttryck}

Min utgångspunkt är, utifrån ett kunskapsteoretiskt perspektiv, att dessa ämnes- och kursplanebeskrivningar innehållsligt är mer avpassade än tidigare kursplaner. Skrivningarna är mer utförliga och sammansatta än de föregående. Formuleringarna kan bidra till en större förståelse för kunskapens komplexitet. Det finns trots det synpunkter och invändningar att göra mot den bild som framför allt kunskapskraven samlat ger av teater som skolämne inom gymnasieskolan. Min huvudpoäng är att det finns en risk att kunskap som tar sig praktiska/kroppsliga uttryck osynliggörs eller hamnar i skymundan för en teoretisk/språklig värdering av ämnet. Med språklig menar jag i det här fallet; det talade och skrivna ordet. Det har kommit larmrapporter om elevers sjunkande läs- och skrivförmåga, vilket har lett till satsningar av

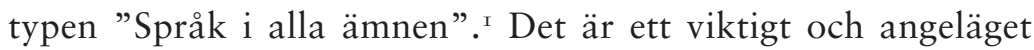
utvecklingsområde samtidigt som risken att värderingen av ett kunskapande som sker $i$ och med kroppen förbises till förmån för verbalt och skriftligt språkliggörande. Alla tre formerna behövs. Verbalt, skriftligt och kroppsligt kunskapande. Ingen hierarkisk ordning i övrigt utan en påminnelse om den kroppsliga kunskapens betydelse.

\section{Styrdokument inom gymnasieskolan}

Beskrivningen av det centrala innehållet fungerar väl för att åskådliggöra en grundläggande kurs i teater på gymnasienivå. Det samlade innehållet ger förutsättningar för att utveckla elementära kunskaper i teater som skolämne. Kursen är en av tre obligatoriska delkurser; scenisk gestaltning I, 2 och 3, vilka bildar 
en progression under de tre gymnasieåren. Det sätts ett nytt kursbetyg i varje avslutad kurs som i de flesta fall löper över ett läsår. Det finns därtill andra valbara kurser som skolan och eleverna kan välja som inte behandlas här. ${ }^{2}$

Styrdokumenten stakar ut en väg vartåt utbildningen bör sträva. I dagens kursplaner på gymnasiet finns det skrivningar i ämnets syfte som avser att på ett mer klargörande sätt (i förhållande till tidigare kursplaner) uttrycka specifika färdigheter och förmågor. Betygskriterierna (kunskapskraven) är från och med GYI I formulerade på liknande sätt i alla ämnen inom gymnasiet, i ett försök att skapa ett enhetligt system. ${ }^{3}$ Det mest anmärkningsvärda är att en kurs som benämns som "scenisk gestaltning" innefattar kunskapskrav som i huvudsak skulle kunna tolkas som teoretiska/språkliga (i meningen; det talade och skrivna ordet); beskriver, redogör, diskuterar, analyserar, tolkar och värderar. De kunskapskrav som direkt berör gestaltningen handlar om; gestalta, kommunicera och samarbeta.

Det kunskapsteoretiska perspektiv som jag utgår ifrån är en icke-dualistisk, relationell och praktikgrundad kunskapssyn. ${ }^{4}$ Det innebär att kropp och tanke är en enhet, inte separerade. Det betyder dessutom att ett praktiskt handlande innefattar teori och inte är tillämpad teori. I mötet mellan elev och lärare utvecklas kunskap som en transaktionell relation. ${ }^{5}$ Det vill säga kunskap är ingen statisk form utan ett rörligt innehåll. Både elever och lärare bidrar till att kunskapen tar gestalt och att innehållet som för tillfället bearbetas åskådliggörs. Det är inget oföränderligt tillstånd utan det förflyttas i en pågående förbindelse med och påverkan på varandra.

De senaste läroplansreformerna har bidragit till ett vidgat kunskapsbegrepp där fakta, färdighet, förtrogenhet och förståelse medför en sammansatt kunskapsteori och att kunna gestalta innefattar alla fyra aspekter. För att exempelvis inom teater kunna gestalta en bagare så behövs en viss förståelse och fakta kring vad en bagare gör men även färdighet att i kroppen kunna utföra rörelser som exemplifierar en bagare och förtrogenhet med att gestalta rollfiguren inför publik. Genom att eleven får träna på de fyra aspekterna samtidigt så utvecklas olika förmågor. Lärare idag ska värdera och bedöma elevers förmågor i olika ämnen. 


\section{Kunskapskrav eller kravfylld kunskap?}

Nedan följer ett utdrag från kunskapskraven i kursen scenisk gestaltning I:

Resultatet av undervisningen ska av läraren/lärarna värderas, bedömas och betygssättas utifrån följande kunskapskrav: ${ }^{6}$

\section{Betyget $\mathrm{E}$}

Eleven gestaltar med tillfredsställande resultat några enkla uttryck med kroppen och rösten. Eleven beskriver översiktligt hur teaterns scenografi, mask, kostym, ljud och ljus ingår i sceniska gestaltningar samt gestaltar inom något av dessa områden. Eleven redogör översiktligt för uppbyggnaden av några enkla sceniska berättelser.

Eleven beskriver översiktligt hur några av teaterns uttrycksområden samverkar samt kommunicerar med viss säkerhet med publik genom att använda några av teaterns uttrycksmedel. Eleven samarbetar med viss säkerhet i olika gestaltningsgrupper. Dessutom diskuterar eleven översiktligt det egna skapandet samt värderar det med enkla omdömen. Eleven gör en enkel analys av någon annans sceniska gestaltning samt tolkar denna. I sin analys använder eleven med viss säkerhet relevanta begrepp.

\section{Betyget D}

Betyget $\mathrm{D}$ innebär att kunskapskraven för $\mathrm{E}$ och till övervägande del för C är uppfyllda.

\section{Betyget C}

Eleven gestaltar med tillfredsställande resultat några uttryck med kroppen och rösten. Eleven beskriver utförligt hur teaterns scenografi, mask, kostym, ljud och ljus ingår i sceniska gestaltningar samt gestaltar inom några av dessa områden. Eleven redogör utförligt för uppbyggnaden av några sceniska berättelser.

Eleven beskriver utförligt hur några av teaterns uttrycksområden samverkar samt kommunicerar med viss säkerhet några med publik genom att använda teaterns uttrycksmedel. Eleven samarbetar med viss säkerhet i olika gestaltningsgrupper. Dessutom diskuterar eleven utförligt det egna skapandet samt värderar det med nyanserade omdömen. Eleven gör analyser av andras sceniska gestaltningar samt tolkar dessa. I sina analyser använder eleven med viss säkerhet relevanta begrepp. 


\section{Betyget B}

Betyget B innebär att kunskapskraven för $\mathrm{C}$ och till övervägande del för A är uppfyllda.

\section{Betyget A}

Eleven gestaltar med gott resultat flera komplexa uttryck med kroppen och rösten. Eleven beskriver utförligt och nyanserat hur teaterns scenografi, mask, kostym, ljud och ljus ingår i sceniska gestaltningar samt gestaltar inom flera av dessa områden. Eleven redogör utförligt och nyanserat för uppbyggnaden av flera komplexa sceniska berättelser.

Eleven beskriver utförligt och nyanserat hur flera av teaterns uttrycksområden samverkar samt kommunicerar med säkerhet med publik genom att använda flera av teaterns uttrycksmedel. Eleven samarbetar med säkerhet i olika gestaltningsgrupper. Dessutom diskuterar eleven utförligt och nyanserat det egna skapandet samt värderar det med nyanserade omdömen och formulerar vägar för hur skapandet kan utvecklas. Eleven gör komplexa analyser av andras sceniska gestaltningar samt tolkar dessa. I sina analyser använder eleven med säkerhet relevanta begrepp.

Teaterämnet består på ett självklart sätt av analys och tolkning, här finns ingen motsättning utifrån mitt perspektiv. När en elev till exempel fysiskt arbetar med en rollfigur så innefattar gestaltandet både analys och tolkning. Men i kunskapskravens skrivningar kan analysen och tolkningen tydas som kopplade till det talade och skrivna ordet:

Eleven redogör utförligt och nyanserat för uppbyggnaden av flera komplexa sceniska berättelser.

Eleven gör komplexa analyser av andras sceniska gestaltningar samt tolkar dessa.

Det finns ingenting i skrivningarna som skulle stödja ett antagande om att analys och tolkning även sker i det gestaltande arbetet, i kroppen. Skrivningarna ovan kan bidra till en dualistisk syn på kunskap innefattande först ett görande (i kroppen) och därefter ett reflekterande (i huvudet). 
Uppbyggnaden av en komplex scenisk berättelse och komplexa analyser kan ges kroppsliga uttryck som kan värderas, men den omedelbara tolkningen kan bli att eleven förväntas redogöra med hjälp av orden. Den andra formuleringen: "eleven gör komplexa analyser av andras gestaltningar samt tolkar dessa" blir svårare att tyda som att eleven visar vad hen kan med ett kroppsligt uttryck. Det lär bli en muntlig eller skriftlig analys som blir föremål för lärarens värdering av kunskapen. (Jag har i min skrivprocess sökt en synonym till ordet tolka - ett av förslagen blev "uttrycka i ord").

Som komplement till de tre obligatoriska kurserna i teaterämnet så finns ytterligare en obligatorisk kurs: Teaterteori. I den kursen finns beskrivningar i kunskapskraven liknande de från kursen Scenisk gestaltning $I$ : redogör, analyserar, tolkar och beskriver. I det fallet är det rimligt att kraven innebär att det muntliga och skriftliga ordet hanteras som del av en reflektion över en gestaltning, en text och/eller en föreställning. Mina invändningar gäller att liknande skrivningar dominerar även kunskapskraven för kursen Scenisk gestaltning I.

Dessutom finns det ingen skillnad i värderingen i ett par av kunskapskraven mellan betyget för $\mathrm{E}$ och $\mathrm{C}$ vad gäller progression i de områden som handlar om ett gestaltande arbete. Exempelvis så formuleras skrivningen vad gäller att bedöma elevens samarbete som: "Eleven samarbetar med viss säkerhet i olika gestaltningsgrupper " med samma skrivning på både Eoch C- nivå. Först i kunskapskrav för A- nivå finns det en progression i skrivningen "Eleven samarbetar med säkerhet i olika gestaltningsgrupper”. Det får som konsekvens att eleverna inte kan visa progression i samarbetet, som är en central förmåga i teaterarbetet. Konsekvensen blir att kunskap som tar sig praktiskt uttryck (som förmåga att samarbeta i en gestaltning) värderas olika än övriga förmågor. Det här kan tolkas som ett uttryck för en svårighet att formulera sig kring praktisk kunskap, vilket jag återkommer till.

\section{Centralt innehåll som utgångspunkt för undervisningen}

Det finns en fara i att lärare börjar planera sin undervisning utifrån kunskapskraven istället för med utgångspunkt i det centrala 
innehållet. ${ }^{7}$ Styrdokumenten är disponerade så att syftet med ämnet introduceras, därefter kommer en beskrivning av varje kurs där utvecklandet av vissa färdigheter, kunskaper och förmågor betonas (som är framskrivna i syftet, se nedan). I kursplanen formuleras även det centrala innehållet. Slutligen redovisas kunskapskraven. Om läraren planerar sin undervisning utifrån VAD (det vill säga vilket innehåll ska bearbetas för att ge eleverna möjligheter att utveckla vissa förmågor) så följer metoderna (HUR) som en konsekvens av det och man kan som lärare svara på VARFÖR det valda innehållet är centralt. Det är utgångspunkten för didaktiskt förankrad undervisning.

Med dagens detaljerade kunskapskrav finns en risk att planeringen av undervisningen startar i kunskapskravens formuleringar istället för i det centrala innehållet eftersom lärare känner en press på sig att hinna med allt som ska prövas enligt kunskapskraven. ${ }^{8}$ Hur skulle det kunna vara annorlunda? Främst behövs det mer forskning inom teaterämnet där lärare ges möjlighet att utveckla förståelse kring vad det innebär att utveckla vissa förmågor, färdigheter och kunskaper. I styrdokumenten, beskrivs teaterämnets syfte, i termer av färdigheter, förmågor, förståelse och kunskaper.

Undervisningen i ämnet teater ska ge eleverna förutsättningar att utveckla följande:

I. Färdigheter i att använda kroppen och rösten som sceniska uttrycksmedel.

2. Färdigheter i att använda scenografi, kostym, mask, ljus och ljud som sceniska uttrycksmedel.

3. Kunskaper om den sceniska berättelsens uppbyggnad.

4. Kunskaper om regi och dess betydelse för helheten.

5. Förståelse av hur teaterns olika uttrycksområden samverkar.

6. Färdigheter i att med teaterns uttrycksmedel kommunicera med en publik.

7. Förmåga att samarbeta i grupper.

8. Förmåga att reflektera över det egna skapandet.

9. Förmåga att analysera och tolka olika sceniska gestaltningar.

Io. Kunskaper om konstarten teater ur ett samtida och historiskt perspektiv. 
Däremot finns det i styrdokumenten ingen problematisering eller diskussion kring relationen mellan kunskaper, färdigheter och förmågor. Skolverket hänvisar till ett särtryck ur Skola för bildning ${ }^{9}$ som tillsammans med de nya läroplanerna utgör utgångspunkten för en diskussion i skolan om kunskap och lärande, om bildning och skolans uppgifter. ${ }^{10}$

Forskning som undersöker kunskap som tar sig praktiska och gestaltande uttryck är sällsynt inom teaterämnet men det är ingen anledning till att låta sig kidnappas av formuleringar där ett språkligt uttryck (det talade och skrivna ordet) premieras. Det finns studier inom dans och musik som skolämnen i Sverige. ${ }^{\text {II }}$ Generellt behövs fler studier som undersöker kunskap som är praktisk/kroppslig till sitt uttryck och hur den kan värderas inom skolan. I annat fall kan undervisningen resultera i kunskap om ämnet istället för kunskap $i$ ämnet. Åtminstone är det värt att vara uppmärksam på och sträva efter en balans i vad man kan och vad man vet i ämnet. Det i sig handlar om olika kunskapsformer som inte utesluter varandra utan samspelar och stärker förmågorna i ett ämne som teater. ${ }^{\mathrm{I} 2}$ Lärare bör vara medvetna om detta och erbjuda eleverna möjligheter att utveckla alla de olika förmågor som teaterämnet består av.

\section{Kroppslig kunskap}

I min avhandling ${ }^{13}$ diskuterar jag hur teaterkunnande som gestaltning består av både praktisk och teoretisk kunskap. De studier som ingår i avhandlingen bidrar med att visa hur kroppen formerar kunskap. En av slutsatserna är att kroppslig kunskap utvecklas genom att delta i teaterundervisning och att teater som skolämne utvecklar kroppslig bildning, i avhandlingen formulerat som bodybildung. Min tolkning av de skrivningar som finns i teaterkurserna på gymnasienivå är att de ska legitimera ämnet som ett studieförberedande ämne. Ämnet har skrivits fram som både praktiskt och teoretisk istället för att hävda ämnets särart som i huvudsak ett praktiskt ämne med teori $i$ praktik vilket är kunskapsbasen för en gestaltning. Det finns en risk att, i stället för att legitimera ämnet som del av en praktisk kunskapstradition där kunskapen främst tar sig praktiska uttryck, hävdas dess 
teoretiska värde. Det kan även ha att göra med svårigheterna och ovanan att värdera praktisk kunskap. I ett försök att legitimera ämnet som skolämne så blir det viktigt att eleverna kan formulera sig i skrift och tal. Om tillvägagångssättet får som konsekvens att värderingen av det skrivna och talade ordet väger tyngre när det kommer till betygssättning så görs ämnet en björntjänst. Då värderas inte kunskap som i huvudsak visar sig i handling, som ett kroppsligt uttryck, som praktisk kunskap. Förklaringen till det kan helt enkelt vara uttryck för en ovana vid att formulera sig kring kunskap som visar sig i handling.

En alternativ väg framåt är att argumentera för att lärare behöver utveckla ett professionellt språk som grund för värdering av praktisk kunskap. Det är inte samma sak som att säga att lärarna inte är professionella. Det handlar snarare om att delar av den praktiska kunskapen kan beskrivas som tyst eller underförstådd. ${ }^{14}$

Michael Polanyi ${ }^{15}$ tar hjälp av begreppet tacit knowing, kunnandet, som bestående av en närbelägen (proximal) och en avlägsen (distal) sida. Tyst kunnande och uppdelningen i proximal och distal beskriver hur delar av det tysta, närmare bestämt det distala kan benämnas och uttalas, men är beroende av det proximala och de kan bara förstås tillsammans. Det proximala är inte möjligt att prata om menar Polanyi eftersom det är en kroppslig, fysisk sensation. Till skillnad från gestaltpsykologin, som menar att det att utveckla kunskap om någonting är en mental process, så hävdar Polanyi att det proximala, tysta eller underförstådda är grunden för all kunskap, vilket innefattar ett aktivt erfarande. En person måste aktivt handla i förhållande till någonting och därigenom utveckla ett kunnande. ${ }^{\mathrm{I}}$

Polanyi beskriver genom exemplet upplevelsen av att komma in i ett rum och omedelbart bilda sig en uppfattning om det är ett stökigt, rent, trivsamt och/eller smutsigt rum. Det är inte självklart att omedelbart uppfatta alla detaljer som ger ett helhetsintryck men Polanyi förklarar att det är detaljerna som är centrala för att uppfatta helheten. På liknande sätt kan en gestaltning upplevas som bra, ofokuserad, engagerande eller trevande. Orden blir, när de är tagna ur sitt sammanhang, värdelösa. Vad är det som är bra eller engagerande? Till skillnad från rummet som endera är rent eller smutsigt så är orden laddade av subjektiva föreställningar om 
vad som exempelvis är bra. För att kunna förklara en helhet av en gestaltning som bra (i betydelsen fungerande i den situation gestaltningen beskriver) så behövs formuleringar kring detaljerna, vad är det i de enskilda delarna som bidrar till att helheten upplevs som bra? Min erfarenhet av att arbeta med olika lärarlag i både dans, musik och teater är att lärare ofta är överens om vad som är bra. ${ }^{17}$ Däremot kan det vara olika delar, eller aspekter av helheten som olika lärare uppfattar bidrar till att någon upplever en gestaltning som bra. ${ }^{18}$ Genom att exempelvis titta på filmat material av elevers gestaltningar och börja formulera sig kring vad det specifikt är som bidrar till att gestaltningen upplevs som bra så kan ett ämnesspecifikt språk utvecklas och ta form. Det är viktigt, inte enbart för att utveckla ett professionellt språk mellan lärare, utan även för att planera undervisning och för att kommunicera med elever i undervisningen, som en del av omdömes och utvecklingssamtal. Därtill är det centralt i syfte att utveckla kunskap om hur praktisk kunskap kan värderas och på sin egen grund legitimeras som skolämne. ${ }^{19}$

Det är möjligt att prata om kvalitativa aspekter av en gestaltning som bidrar till att den upplevs som bra. Eventuellt kan det hävdas att det krävs en annan typ av värdering för att formulera sig kring "omätbara kvaliteter". ${ }^{20}$ De är inte mätbara i traditionell mening (Strannegård tar som exempel att mäta hållfastheten i en bro) men kvaliteten går att artikulera, framför allt i förhållande till exempel, såsom ett filmat exempel av en god gestaltning. Om man kan formulera sig kring vilka de aspekterna är så börjar man närma sig ett kvalitativt samtal om en god eller fungerande gestaltning som kan bli användbart i mötet med elever i undervisningen och/eller vid exempelvis ett omdömessamtal där lärarens värdering av arbetet och elevens kunnande ska kommuniceras. På så sätt kan ett språkliggörande av en kunskap som visar sig i ett praktiskt/gestaltande uttryck komplettera talade och skrivna analyser. Det kan beskrivas som fysiska analyser för att förtydliga att kunskapen visar sig i kroppen. Det kan utifrån ett vidgat språkbegrepp diskuteras om inte också talade och skrivna analyser är en form av (litterär) gestaltning. Om konsensus kan nås att kalla de tre olika typerna av uttryck för någon form för gestaltning är hur som helst min poäng att det är olika saker. Tre olika lärandeobjekt som är viktiga för att utveckla olika förmågor och som bör ses som kompletterande varandra. 
Det handlar dessutom om att erkänna vissa av aspekterna som kvalitativa i den meningen att det är möjligt att som lärare exempelvis uttala sig om en fungerande gestaltning. Det kan finnas en risk att estetiska ämnen i skolan upplevs som ett frirum där allt som görs, gestaltas, uttrycks och formuleras är bra. Alla har rätt att uttrycka sig och ingen, varken lärare eller andra elever har lov att ha en åsikt om det som produceras. Här visar sig björntjänst nummer två. Som Bailin ${ }^{21}$ konstaterar så kan man inte lära någon något om man inte värderar det som visas, gestaltas, uttrycks eller skapas.

Let us look, for example, at the idea that creative thinking involves the suspension of judgement. I would argue that judgement is very much involved throughout the process of creating, that one evaluates all the time, and that, indeed, one must. The initial recognition of a problem as a problem, or identification of an area of exploration, is very much a product of judgement, as is the determining of a general direction for solution or way of proceeding. It is because one has expertise in an area and is immersed in its intricacies that one develops the judgment that makes it possible to see certain phenomena as in need of explanation or certain directions of exploration as viable (Bailin I998, s. 4I).

Lärarens uppgift måste vara att hjälpa eleven att utveckla sitt uttryck, sin gestaltning, sitt skapande eller vad det nu är som produceras i den kreativa processen. Om eleven inte möter något motstånd, om allt som görs alltid är rätt och bra så finns det en risk att engagemanget avtar. Det är möjligt och nödvändigt att utmanas i sitt skapande och här fyller läraren en viktig funktion genom att identifiera problem, genom att värdera och visa vägar för hur arbetet kan utvecklas. Men för att kunna göra det på ett nyanserat och etiskt väl avvägt sätt behöver först och främst formuleringar utvecklas kring vilka kvalitetskriterier som lärare baserar sitt omdöme och sin värdering på. ${ }^{22}$

\section{Likvärdighet eller likformighet?}

Det är dessutom ett möjligt sätt att undvika den fälla som kunskapskraven kan få lärare att falla i, där läraren istället för att vara trogen sitt ämne blir slav under kraven som inte är skriva utifrån 
ämnesspecifika förutsättningar utan utifrån tanken om likvärdighet. Björntjänst nummer tre uppenbarar sig. I en täckmantel och villfarelse att det går att generalisera kunskapskrav mellan ämnen och i en hel nation kan lärare börja fjärma sig från ämnes kärna. Det är allvarligt och kan rentav bli ofördelaktigt. Ofördelaktigt i den bemärkelse att skolan förminskas till en treämnesskola där läsa, räkna och skriva är de förmågor som undervisningen främst består av och som bedöms. Eleverna skulle på så sätt inte erbjudas möjligheter att utveckla andra förmågor som utifrån ett bildningsperspektiv är avgörande för att utvecklas och bli människa. Jag har träffat lärare i praktisk-estetiska ämnen som sliter med att konstruera skriftliga uppgifter där eleverna kan formulera sig om sitt kunnande i ämnet, istället för att ges tillfälle att gestalta eller producera i ämnet och därigenom visa vad man kan. Vad eleverna gestaltar och/eller producerar kan komma att bli det resultat som det därefter ska analyseras över.

Likvärdighet kan anses vara ett rimligt mål inom skolan, men det beror på vilken betydelse ordet ges. ${ }^{23}$ Det blir inte per automatik en likvärdig skola genom att samma värdeord används i kunskapskraven vilket också Skolverket framhåller (se hela citatet, not 4):

Kvaliteten i elevens kunnande beskrivs $i$ kunskapskraven med värdeord eller progressionsord. Flera av dessa ord aterfinns i flera ämnen. Vad värdeorden betyder $i$ en bedömningssituation avgörs av sammanhanget (Skolverket u.å. Betygssättning, stycke 5, under rubrik Kunskapskraven).

Det blir paradoxalt att påstå att ord får sin betydelse i de sammanhang de används och att det inte är möjligt att göra generella definitioner, samtidigt är det precis det som sker i och med värdeordens utformande. Idag raljeras det från studentvagnar med paroller där eleverna använder värdeorden: "Vi har tagit studenten, på ett utförligt och nyanserat sätt". Det blir inte trovärdigt och eleverna ser igenom lärarnas försök att förhålla sig till och tolka vad utförligt och nyanserat kan innebära i just det här ämnet och i just den här uppgiften. Det kan leda till det som Carlgren $^{24}$ varnar för; att lärarna skapar genvägar för eleverna att 
nå upp till kraven, istället för att fördjupa kunskaperna genom meningsfull undervisning.

Hur ska då likvärdighet uppnås? Först och främst måste lärarna som Skolverket också beskriver i citatet, få möjlighet att identifiera vilka aspekter av elevexempel som bedömningarna utgår ifrån. Det är inget enkelt arbete och här bör lärarna ges tillfälle att beforska sin egen praktik, gärna tillsammans med kollegor. För att utreda vad det innebär att vara kunnig i ett ämne krävs ett systematiskt forskningsarbete. Resultatet av det måste i sin tur genomsyra undervisningen så att eleverna har fått möjlighet att utveckla de olika aspekterna som bedömning förhåller sig till. Då går det att uppnå likvärdighet på ett lokalt plan, där lärare som arbetar på samma skola har en likvärdig syn på innehåll, undervisning och bedömning. Därefter kan samtal föras med andra skolor och kommuner om hur man arbetar med specifika arbetsområden och på vilka grunder bedömningar görs. Idag pågår ett sådant arbete inom Stockholms stad där Lärarnas forskningskonferens är ett föredömligt exempel på hur lärare kan dela kunskap om undervisning med varandra. ${ }^{25}$

I det dagliga arbetet som lärare kan frågan om likvärdighet hanteras genom att erbjuda eleverna möjligheter till lärande utifrån individens förförståelse. Alla elever uppfattar samma fenomen på olika sätt vilket blir centralt att som lärare förhålla sig till om man vill skapa förutsättningar för likvärdighet i sitt klassrum. ${ }^{26}$ Även det förutsätter ett systematiskt arbete i syfte att få syn på elevernas olika förförståelse och kunnande om det innehåll som för stunden behandlas. För den lärare som ska arbeta i morgondagens skola måste grunden för arbetet vara en lärardriven forskningspraktik, om lärare ska kunna förhålla sig till kunskaps- och lärandeteorier som förändrat lärares arbete under de senaste decennierna.

För att återvända till problematiken där de så kallade praktisk-estetiska ämnena riskerar att undermineras av teoretiska/ språkliga överbyggnader så har jag i mitt arbete valt att tolka exempelvis skrivningar som: "Eleven redogör utförligt och nyanserat för uppbyggnaden av flera komplexa sceniska berättelser" som att redogörelsen också kan ske i kroppen. Jag har i min avhandling ${ }^{27}$ kunnat visa hur ett "utförligt och nyanserat" sätt att gestalta kan beskrivas. Det formuleras i resultaten som ett mer 
förfinat urskiljande av olika aspekter av ett fenomen. Genom att jag arbetade tillsammans med lärarlag där vi planerade, reviderade och analyserade undervisning med fokus på specifika lärandeobjekt kunde vi systematiskt undersöka och beskriva innebörden av en högre nivå av kunnande. Eftersom lärarna i studien bidrog med sin kunskap och förförståelse om det specifika lärandeobjektet så kunde olika aspekter av det vi undersöktes urskiljas. När vi därefter mötte eleverna i undervisningen så bidrog även elevernas kunskap, förförståelse och hur undervisningen togs emot till att utveckla kunskap om lärandeobjektet. ${ }^{28}$ Resultatet av likande studier är en framkomlig väg för lärare att planera, genomföra och bedöma utfallet av sin undervisning. Lärare utvecklar kunskap om det som är det centrala i uppdraget, att undervisa i sitt ämne, och professionen byggs stark inifrån praktiken utan risk för vare sig fallgropar eller björntjänster.

\section{Slutnoter}

I. Skolverket, 20I2 Språk $i$ alla ämnen. Språk-eller att byta en bromskloss.

2. Se Skolverkets hemsida för beskrivning av alla teaterkurser: http:// www.skolverket.se/laroplaner-amnen-och-kurser/gymnasieutbildning/gymnasieskola/sok-amnen-kurser-och-program/subject. htm?lang=sv\&subjectCode=tea\&tos=gy

(hämtad 2OI5-O2-I5).

3. " Kunskapskraven är konstruerade utifrån ämnets eller kursens långsiktiga mål och centrala innehåll. Kvaliteten i elevens kunnande beskrivs i kunskapskraven med värdeord eller progressionsord. Flera av dessa ord återfinns i flera ämnen. Vad värdeorden betyder i en bedömningssituation avgörs av sammanhanget. En lärare kan till exempel tolka ordet "enkla" på ett sätt när läraren bedömer en elevs resonemang i relation till ett konkret ämnesinnehåll och på ett delvis annat sätt i relation till ett annat ämnesinnehåll i ett annat arbetsområde" (Skolverket 20I6, Betygssättning, stycke 5, under rubrik Kunskapskraven).

4. Ingrid Carlgren, 20I5. Kunskapskulturer och undervisningspraktiker. Michael Polanyi, I998. Personal knowledge. Towards a PostCritical Philosoph. 
5. Dewey \& Bentley,1949. Knowing and the known.

6. Skolverket,u.å.a. Läroplan för gymnasieskolan. Ämne - teater.

7. Carlgren, 20I 5 a.

8. jämför "hinna med kursen", Carlgren \& Marton, 2002 Lärare av imorgon.

9. Läroplanskommittén (I994). Bildning och kunskap: särtryck ur Läroplanskommitténs betänkande Skola för bildning (SOU I992:94).

Io. Läroplanskommittén (I994).

II. jämför Andersson, 20I6. Communication and shared understanding of assessment: a phenomenological study of assessment in Swedish upper secondary dance education.; Andersson \& Ferm Thorgersen, 20I5. Bedömning av danskunnande - uttryck, respons och värdering inom ett estetiskt ämne.; Carlgren \& Nyberg, 20I 5 Från ord till rörelser och dans - en analys av rörelsekunnandet $i$ en dansuppgift.; Zandén \& Ferm Thorgersen, 20 I 5.Teaching for learning or teaching for documentation?: Music teachers' perspectives on a Swedish curriculum reform.

I2. jämför Carlgren 20I 5a; Elliot Eisner, Cognition and curriculum reconsidered; Elliot Eisner, Assessment and evaluation in education and the arts; Paul Hirst, Knowledge and the curriculum: a collection of philosophical papers.

I3. Pernilla Ahlstrand, 20I4. Att kunna lyssna med kroppen: en studie av gestaltande förmåga inom gymnasieskolans estetiska program, inriktning teater.

I4. Carlgren 20 I $5 \mathrm{a}$

I 5. Polanyi, I958/I998. Personal knowledge. Towards a Post-Critical Philosophy. Polanyi, I967/2009. The tacit dimension. Polanyi, 2013. Den tysta dimensionen.

I6. Se en fördjupad diskussion om tyst kunnande i avhandlingen Att kunna lyssna med kroppen i Ahlstrand, 20I4. http://www.diva-portal.org/smash/get/diva2:735064/FULLTEXTor.pdf

I7. Jag har arbetat med olika skolutvecklingsprojekt med lärarlag på gymnasienivå, bland annat med modellen learning study. 
I 8. Jämför Sadler, 20I2. Assuring academic achievement standards: from moderation to calibration, Assessment in Education (2OI2) samt Marton \& Booth, 2000. Om lärande.

I9. Jämför Ahlstrand 20I5, 20I6. Ferm Almqvist, Vinge, Väkevä \& Zandén, 2017. Assessment as learning in music education: The risk of 'criteria compliance' replacing 'learning' in the Scandinavian countries. Zandén, 2016. The Birth of a Denkstil: Transformations of music teachers' conceptions of quality in the face of new grading criteria. Ferm Thorgersen, 20I 5. Grundskolelevers lärande som estetisk kommunikation: aspekter av översättning och delaktighet.

20. Jämför Strannegård, 2007. Kvalitet på modet.

21. Bailin, I998. Creativity in context.

22. Jämför Andersson, 2016a. Teacher's conceptions of quality in dance education expressed through grade conferences.; Andersson, 20I6b. Communication and shared understanding of assessment: a phenomenological study of assessment in Swedish upper secondary dance education.

23. Jämför Englund \& Quennerstedt, 2008. Likvärdighetsbegreppet $i$ svensk utbildningspolitik.

24. Carlgren, 20I 5b. Tänk om....(den 'nya kunskapsskolan' inte är en kunskapsskola).

25. Se hemsida: http://www.pedagogstockholm.se/stockholm-teachingand-learning-studies/lararnas-forskningskonferensi/

26. Jämför Ferm, 20II. Assessment of musical knowledge from a life-world-phenomnological perspective : The challenge of conceptualising and communication.

27. Ahlstrand, 20I4.

28. Ett lärandeobjekt är en viss insikt, färdighet eller förmåga som eleverna förväntas utveckla, oftast under en eller ett par lektioner utifrån ett väl avgränsat innehåll. Marton \& Tsui 2004; Marton \& Pang 2006. 


\section{Referenser}

Ahlstrand, P. 20I4. Att kunna lyssna med kroppen: en studie av gestaltande förmåga inom gymnasieskolans estetiska program, inriktning teater. Stockholm: Institutionen för etnologi, religionshistoria och genusvetenskap, Stockholms universitet.

Ahlstrand, P. 2015. Learning study i dans. Venue. Linköping: Linköpings universitet. https://www.liu.se/uv/lararrummet/venue/ learning-study-i-dans? $1=$ sv

Ahlstrand, P. 20I6. Man ser på kroppen att de hör pulsen. Venue. Linköping: Linköpings universitet. https://liu.se/uv/lararrummet/ venue/man-ser-pa-kroppen-att-de-hor-pulsen?l=sv

Andersson, N. \& Ferm Thorgersen, C. 20 I 5 . Bedömning av danskunnande - uttryck, respons och värdering inom ett estetiskt ämne. I: B-M Styrke, (red.) Kunskapande i dans: om estetiskt lärande och kommunikation. Stockholm: Liber utbildning.

Andersson, N. 20I6a. Teacher's conceptions of quality in dance education expressed through grade conferences. Journal of Pedagogy, 7(2), I I-32.

Andersson, N. 2016b. Communication and shared understanding of assessment: a phenomenological study of assessment in Swedish upper secondary dance education. Diss.Luleå : Luleå tekniska univ.

Bailin, S. 1998. Creativity in context. In David Hornbrook (ed.) On The Subject of Drama. London: Routledge.

Carlgren, I. \& Marton, F. 2002. Lärare av $i$ morgon. Stockholm: Lärarförbundet.

Carlgren, I. 20I5a. Kunskapskulturer och undervisningspraktiker. Göteborg: Daidalos.

Carlgren, I. 20 I 5 b. Tänk om.... (den 'nya kunskapsskolan' inte är en kunskapsskola). Skola och samhälle, S.O.S. (hämtad 2016-05-I9). Tillgänglig: http://www.skolaochsamhalle.se/flode/skolpolitik/ingrid-carlgren-tank-om-den-nya-kunskapsskolan-inte-ar-en-kunskapsskola/ 
Carlgren, I. \& Nyberg, G. (2015). Från ord till rörelser och dans en analys av rörelsekunnandet i en dansuppgift. I: Forskning om undervisning och lärande: Stockholm: Stockholm: Stiftelsen SAF i samverkan med Lärarförbundet.

Dewey, J. \& Bentley, A.F. I949. Knowing and the known. Boston:

Eisner, E.W. I996. Cognition and curriculum reconsidered. (2. ed.) London: Paul Chapman.

Eisner, E. W. 2007. Assessment and evaluation in education and the arts. In L. Bresler (Ed.), International Handbook of Research in Arts Education, 423-426. Amsterdam: Springer.

Englund, T. \& Quennerstedt, A. 2008. Likvärdighetsbegreppet i svensk utbildningspolitik i Englund \& Quennerstedt (red.) 2008. Vadå likvärdighet? Göteborg: Daidalos.

Ferm, C. 20II. Assessment of musical knowledge from a life-world-phenomnological perspective: The challenge of conceptualising and communication. Hellenic Journal of Music, Education, and Culture, 2(3), 38-45. Retrieved from http://urn. kb.se/resolve?urn=urn:nbn:se:ltu:diva-I0767

Ferm, C. 20I 5. Grundskolelevers lärande som estetisk kommunikation: aspekter av översättning och delaktighet. I: B-M Styrke, (red.) Kunskapande i dans: om estetiskt lärande och kommunikation. Stockholm: Liber utbildning.

Ferm Almqvist, C., Vinge, J., Väkevä, L., \& Zandén, O. 2017. Assessment as learning in music education : The risk of 'criteria compliance' replacing 'learning' in the Scandinavian countries. Research Studies in Music Education, 39(I), 3-18. https://doi. org/IO.I I 77/I32II03XI6676649

Hirst, P. H. 1974. Knowledge and the curriculum: a collection of philosophical papers. London: Routledge.

Marton, F. \& Booth, S. 2000. Om lärande. Lund: Studentlitteratur.

Marton, F. and Tsui, A. B.M. with Chik, P.M., Ko, P. Y., Lo, M. L., Mok I. A.C., Ng, F.P., Pang, M. F., Pong, W. Y., Runesson, U. 2004. Classroom Discourse and the Space of Learning. Mahwah: Lawrence Erlbaum Associates.

Marton, F. \& Pang, M. F. 2006. On some necessary conditions of learning. The journal of the learning sciences. I5 (2), I93-220. 
Polanyi, M. I958/I998. Personal knowledge. Towards a Post- Critical Philosophy. London: Routledge \& Kegan Paul.

Polanyi, M. I967/2009. The tacit dimension. University of Chicago Press ed. Chicago: The University of Chicago Press.

Polanyi, M. 2013. Den tysta dimensionen. Göteborg: Daidalos.

Sadler, D. R. 20I2. Assuring academic achievement standards: from moderation to calibration, Assessment in Education: Principles, Policy \& Practice, I-I 5.

Skolverket. u.å.a.. Estetiska programmet. Läroplaner, ämnen och kurser. (Hämtad 20I6-05-03). Tillgänglig: http://www.skolverket. se/forskola-och-skola/gymnasieutbildning/amnes-ochlaroplaner/sok-program-och-amnesplaner/program. htm? programCode=ESoo $\mathrm{I}$ \&lang=sv

Skolverket. u.å. b. Bildning och kunskap. (Hämtad 20I3-OI-03). Tillgänglig: http://www.skolverket.se/publikationer?id=I35

Skolverket. 20I 2. Språk i alla ämnen. Språk- eller att byta en bromskloss. (Hämtad 20I6-05-I9). Tillgänglig: http://www.skolverket.se/ laroplaner-amnen-och-kurser/gymnasieutbildning/gymnasieskola/ diskutera-och-utveckla/sprak-i-alla-amnen

Skolverket. 20I6. Betygssättning. (Hämtad 20I2-06-2I). Tillgänglig: http://www.skolverket.se/regelverk/fragor-och-svar/fragor-och-svarom-betyg/betygssattning-I.I7334I

Strannegård, L. 2007. Kvalitet på modet. I: Lars Strannegård (red.) Den omätbara kvaliteten. Stockholm: Norstedts akademiska förlag.

Zandén, O. \& Ferm Thorgersen, C. 20I5. Teaching for learning or teaching for documentation?: Music teachers' perspectives on a Swedish curriculum reform. British Journal Of Music Education, 32(I), 37-50.

Zandén, O. 20I6. The Birth of a Denkstil: Transformations of music teachers' conceptions of quality in the face of new grading criteria. Nordisk Musikkpedagogisk Forskning, I7, I97-225. Retrieved from http://urn.kb.se/resolve?urn=urn:nbn:se:Inu:diva-60435 
